Journal of Applied Finance \& Banking, Vol. 11, No. 3, 2021, 129-159

ISSN: $1792-6580$ (print version), 1792-6599 (online)

https://doi.org/10.47260/jafb/1136

Scientific Press International Limited

\title{
Banking Sector Consolidation and Stability in Kenya
}

\author{
Samuel Kiemo $(\mathbf{P h D})^{1}$ and Cyrus Mugo ${ }^{2}$
}

\begin{abstract}
This paper sought to examine the evaluation of competition and stability conditions in the Kenya banking sector amidst adoption various aspects of consolidation. This was achieved by exploring evolution of competition and stability conditions using bank-level and peer-level annual data from 2001 to 2017 for 37 banks. The paper adopted three-step estimation approach; first, estimated two competition measures Lerner Index and Panzar-Rosse $\mathrm{H}$ statistics to assess evolution of competition conditions. Secondly, constructed two stability measures Altman Z - Score and Bankometer S - Score to assess evolution of stability conditions. Thirdly, using panel GMM estimators introduced the estimated competition measures as explanatory variables and re-examined stability conditions to evaluate the role of competition in promoting banking sector stability. The study findings indicate competition conditions have increased and can be characterized as monopolistic competition. The banking sector stability conditions are high and sound, though downward trending. Increase in level of competition promotes stability conditions. The paper concludes that, adoption of various aspect of banking sector consolidation has led to improved competition and stability conditions in Kenya. Banking sectors players should continue implementing and adopting various policies that promote competition and stability such as market driven consolidations.
\end{abstract}

JEL classification numbers: G2, G01, G33.

Keywords: Bank Stability, Consolidation, Competition, Market Power, Lerner Index, Altman Z-Score, Bankometer S-Score, H-statistics.

${ }^{1}$ Central Bank of Kenya.

2 Central Bank of Kenya.

Article Info: Received: August 5, 2020. Revised: August 28, 2020.

Published online: April 12, 2021. 


\section{Introduction}

Financial liberalization was expected to enhance financial sector competition brought by improved efficiency. Coupled with globalization, the liberalized financial sector across both developed and developing markets aimed to accelerate financial innovations, reduce regulatory arbitrage hence increased efficiency which was ultimately expected to spur competition. Banking sector consolidation was considered to be the anchor of the financial linearization whereby the fragmented small-scale financial institutions were encouraged to amalgamate to benefit from economies of scale areas such as, capitalization, market share, operational efficiency (Osoro \& Josea, [1]. The consolidation was to be market-driven or policy-driven or combination of combination of both. Proponents of consolidation argued that fragmentation in the financial sector was creating market distortion due to inefficiencies. However, consolidation critics argues increased banking sector concentration has led to rising financial stability concerns due interconnectedness, over-exposure and creation of large and systemic banks commonly denoted to as 'too big to fail' or highly interconnected banks 'too networked to fail'. Others studies such as Osoro \& Josea [1] argues that any arrangements that could influence the level of market power such as mergers and acquisitions should be better assessed on how they relate to intermediation efficiency and not based on the number of licensed banking operators, which is currently driving consolidation activism.

Globally, financial sector consolidation has been heavily blamed for excessive risk taking by banks in the pre-2007-2009 global financial crisis (GFC) which facilitated increased cross-border operations by international banks.

The clamor for consolidation has led to evolving competition conditions in the financial sector. The verdict as to whether the evolving competition has enhanced financial stability or exacerbates instability remains inconclusive among the policy makers and academia (Agung, Atiti \& Kimani, [2].

Call for consolidation is broadly supported from two arguments namely; economies of scale and organic growth. Economies of scale arguments postulate that the bigger the bank the better. This is mainly due to strong financial muscles; extensive deposit mobilization and improvement in operational efficiency hence give the bank a competitive edge. This line of arguments implicitly means consolidation is meant to save the small banks by creating big banks for long-term sustainability (Osoro \& Josea, [1]. The line of argument has been heavily criticized for creating 'too large to fail or too interconnected banks' posing systemic risks to the economy. Additionally, as banks consolidate they may face diseconomies of scale arising from complex management structures and moral hazard.

The second argument for consolidation postulate that organic growth is not tenable, hence small banks should amalgamate to pursue growth. This is based on the arguments that small banks may not withstand market shocks compared to bigger banks. This based on the fact small banks lack financial measures or other capabilities to mobilize resources to overcome policy or economic shocks. Example of recent policy shock include introduction of interest caps on banks' lending rate 
in Kenya trough the Banking (Amendment) Act of 2016. The interest rate caps resulted in reduction on banks' interest earnings hence clamor for small banks to make strategic partnerships to enable withstanding the policy shock for long-term sustainability. Call for consolidation from this argument fall short since it heavily leans toward financial performance and ignores essence for optimal financial intermediation underpinned by market power.

Call for banking sector consolidation in Kenya has regularly been voiced severally in the past. Most recently was after the Banking (Amendment) Act of 2016. The amendment introduced a cap on banking lending rate at maximum of four percentage points above the Central Bank policy rate (CBR). Additionally, the amendment introduced a cap on the minimum deposit rate at seventy percent of CBR. Later amendments removed caps on deposit rate. The introduction of caps on interest rates was heavily criticized by market players for creating market pricing distortion. However, proponent of the caps on interest rates argued the banking sector was not efficiently pricing its products as evidenced by huge interest rate spread (bank lending rate minus deposit rate). Prior to caps period small banks were recording depressed financial performance and introduction of caps posed greater threat to already precarious financial situation for small banks. To withstand this policy shocks, clamor for consolidation was advanced for small banks to form strategic alliances.

Prior to the Bank (Amendment) Act of 2016, clamor for consolidation was witnessed during the financial instability experienced during the period 2015 and 2016 with closure of three banks in Kenya namely; Dubai Bank, Imperial Bank and Chase bank. The collapse of the three banks which were categorized as small tier bank (Dubai and Imperial bank) and, medium tier bank (Chase Bank) occasioned deposit flight to safety. The small tier banks and medium tier banks experienced tight liquidity conditions as customers' deposit moved to large tier banks which were perceived to be less risky. Additionally, the instability intensified interbank segmentation where large peer banks terminated credit lines with small tier banks. Access to interbank liquidity for small tier banks were at very high rate, hence small tier banks heavily relied on central bank support as lender of last resort as shown by Osoro \& Mureithi [3]. Intervention of central bank support reduced instability risks associated by closure of the three banks. The aftermath of this crisis led to call for consolidation to safeguard small banks against risks associated with industry future instability.

Another episode calling for consolidation was the period 2015 with proposal by The Kenya National Treasury and planning ministry to increase minimum core capital for banks fivefold from KSh. 1 billion to KSh. 5 billion over a period of three years. The proposal was interpreted as call for policy led consolidation in the banking sector. However, the proposal was shelved due to criticism led by the banks prudential regulators and other stakeholders who advocated for market driven consolidation. The critics of the proposal argued the increase of capitalization in quantum terms, does not necessarily safeguard against financial stability risks. They argued using capital ratios expressed as a percentage of the risk weighted assets is 
more superior measure of capital buffers to safeguard against economic shock. At the global scene, the clamor for consolidation was heightened during the aftermath of 2007-2009 global financial crises. This period experienced heighted regulatory reforms such as introduction of Basel III aimed at increasing capital requirements for banks. Similarly, the period witnessed introduction of strong AntiMoney Laundering and Combating-the-Financing-of-Terrorism (AML/CFT) leading to high compliance costs for banks. This led to de-risking trends where international banks exited from cross-border banking by terminating correspondence banking (Kiemo \& Talam [4], IFC [5], IMF [6]). Consolidation was advocated as policy option for banks for long-term sustainability.

\subsection{Status of Banking Sector in Kenya}

Banking sector in Kenya has undergone various phases of consolidations since 1990 's. For example, numerous mergers or acquisition transactions where twentyeight (28) mergers in 1990's, ten (10) in 2000's and three (3) in 2010's, have been completed. On other hand, two (2) acquisitions in 2000's and six (6) in 2010's has also been finalized. As at 2019 discussion are still ongoing on more consolidation. These evolving competition conditions over the last four decades has triggered financial innovations, interconnectedness and complexities due to cross-border operations making Kenya banking sector largest and most developed in the East African region (Kiemo \& Kamau [7].

There is general consensus that consolidation may lead to changes in market power dynamic hence driving competition. Among the benefits of spurring competition in the banking sector is elimination of market power inefficiencies. This is based on the argument that consolidation lead to increased financial muscle through growth in deposits and capital. Additionally, spurring competition enables the market players to create a niche market leading to rise in profitability and assets quality. The financial sector consolidation in Kenya was expected to spur competition. Despite these developments, the banking sector in Kenya still faces myriads of challenges including; comparatively high ratio of non-performing loans (NPLs) in some banks, declining capitalization, declining profitability, skewed lending in favor of government, public and large entities (Kiemo \& Talam [4], Kiemo \& Kamau [7], Central Bank of Kenya (CBK) [8]).

Common performance indicators of banking sector in Kenya reveals worrying trends, rising policy questions on benefit of consolidation in Kenya. Profits were rising in the period 2002-2008, however there was stagnation from 2008-2014, and has been on downward trend from 2014 as indicated by ROA and ROE (Figure 1). 


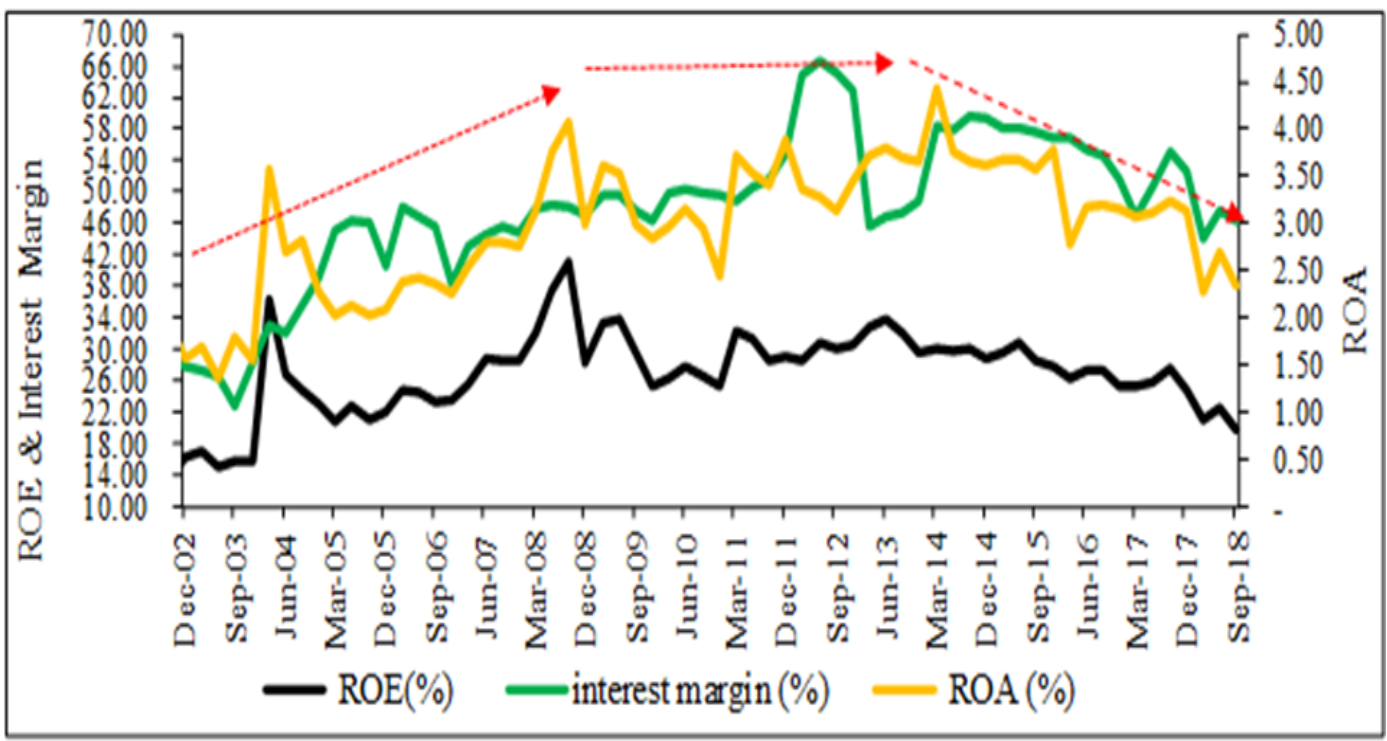

Figure 1: Banks Profitability from 2002-2018

Source: CBK (2019)

Positive growth in capitalization and asset was recorded from 2002 with peak growth recorded in 2008. This positive performance may be attributed to the financial sector reforms and strengthening of regulatory frameworks following financial sector liberalization in 1990s. However, the aftermath of 2008-09 global financial crises (GFC) shock Kenya banking sector asset and capital growth took a downward trend, perhaps on account of portfolio flows, de-risking by global banking corporations from emerging and developing countries and tighter regulatory environment in global market (CBK [8] (Figure 2).

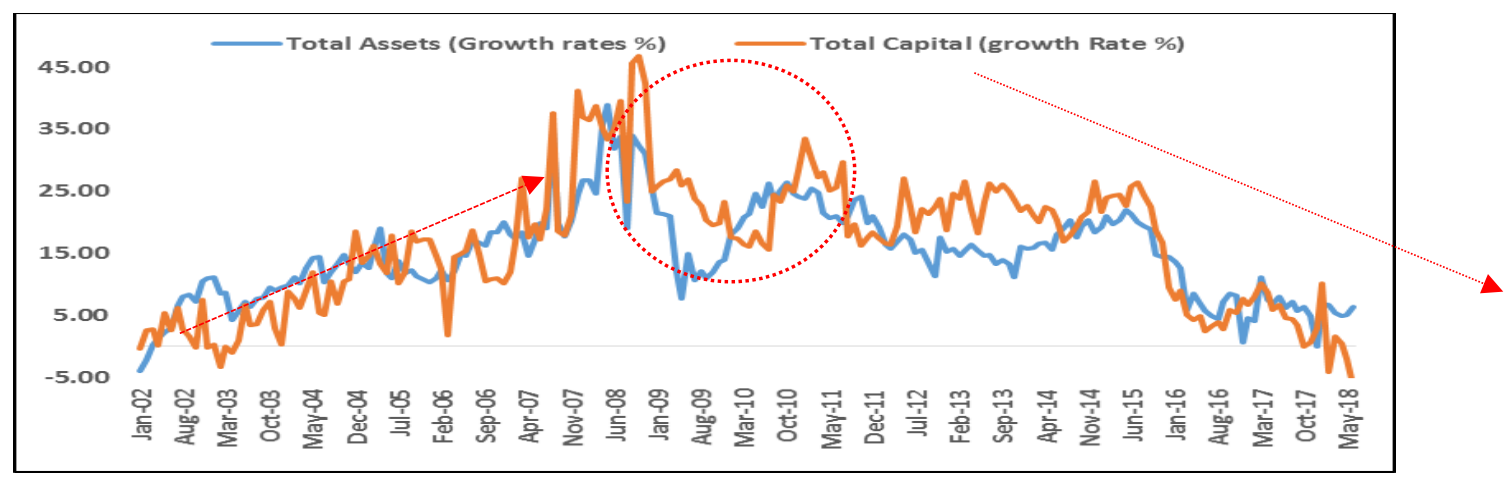

Figure 2: Banks Total Assets \& Capital Growth Rate 2002-2018

Source: CBK (2019) 
Capital ratios has been high and above minimum CBK and Basel requirement indicating overall sector is stable and healthy, however, the aggregate indicators camouflage a significant variation across different peer groups and individual banks. Table 1 reveals that period year 2006 to year 2017 has been characterized by improvement in overall banks financial health. Overall CAR was 18 percent in 2017 (above the 8 percent recommended by Basel core principles and 14.5 percent required by CBK) up from 16.5 percent in year 2006. On downside, sector experienced high levels of non-performing loans for many years before year 2006 averaging about 20 percent. However, the ratio declined significantly to the lowest level of $4.5 \%$ in year 2012. Recently, the ratio has elevated to 12.3 percent as at year 2017 indicating elevated credit risks hence likelihood of bank experiencing financial instability.

Table 1: Banks Financial Stability Indicators (\%)

\begin{tabular}{|c|c|c|c|c|c|c|c|c|}
\hline Selected FSI's & $\mathbf{2 0 0 6}$ & $\mathbf{2 0 0 8}$ & $\mathbf{2 0 1 0}$ & $\mathbf{2 0 1 2}$ & $\mathbf{2 0 1 4}$ & $\mathbf{2 0 1 6}$ & $\mathbf{2 0 1 7}$ & $\mathbf{2 0 1 8}$ \\
\hline Capital Adequacy Ratio & 16.5 & 18.4 & 20.8 & 21.9 & 20.0 & 19.8 & 18.8 & 18.7 \\
\hline $\begin{array}{c}\text { Core Capital to Risk } \\
\text { Weighted assets }\end{array}$ & 16.4 & 16.2 & 18.7 & 18.9 & 16.0 & 17.0 & 16.5 & 17.2 \\
\hline NPL to gross loans Ratio & 21.3 & 8.4 & 6.3 & 4.5 & 5.4 & 9.3 & 12.3 & 12.0 \\
\hline Return on Assets & 2.8 & 2.9 & 3.7 & 3.8 & 3.4 & 3.3 & 3.2 & 3.1 \\
\hline Return on equity & 28.6 & 28.6 & 30.7 & 34.2 & 26.6 & 24.6 & 25.8 & 27.6 \\
\hline Liquidity Ratio & 30.5 & 34.6 & 38.4 & 35.2 & 32.7 & 41.8 & 43.7 & 50.7 \\
\hline
\end{tabular}

Source: CBK (2018)

Empirical findings evaluating market power dynamics using the market concentration measures such as Concentration Ratio (CR) and HerfindahlHirschman Index (HHI) reveals Kenyan banking industry has shifted from oligopolistic competition to monopolistic competition as shown by Concentration Ratio 5 (CR5) $)^{3}$ moving from above 60 percent in 2001 to 47 percent in 2017. The changes in concentration from high concentration to low concentration show that, competition in the banking sector is increasing. On other hand the HerfindahlHirschman Index $(\mathrm{HHI})^{4}$ supports this finding of Kenya banking sector that is becoming more competitive, moving from an index of 1024 in 2002 to 675 in 2017 (Osoro \& Josea [1], Kiemo \& Kamau [7] (Figure 3).

\footnotetext{
${ }^{3}$ CR5 is the sum of the market shares of the 4 largest firms in the market in question. The concentration ratio is calculated as the sum of the market share percentage held by the largest specified number of banks in an industry. The concentration ratio ranges from $0 \%$ to $100 \%$, where $0 \%$ indicates perfect competion and $100 \%$ concentration is Monopoly. A rule of thumb is that an oligopoly exists when the top five firms in the market account for more than $60 \%$ of total market shares.

4 "HHI is the sum of the squares of the market shares of all banks the market. It ranges from 0 to 10,000 . The U.S. Department of Justice considers a market with an HHI of less than 1,500 to be a competitive marketplace, an HHI of 1,500 to 2,500 to be a moderately concentrated marketplace, and an HHI of 2,500 or greater to be a highly concentrated marketplace".
} 




Figure 3 : Concentration Measures of the Banking Industry in Kenya 2001-17 Source: Kiemo \& Kamau (2019)

These trends raise fundamental issues on the effect of consolidation in promoting financial stability in Kenya. As expected, consolidation stimulated competition conditions in Kenya as shown by CR and HHI measures of concentration. However, the expected benefit of increased competition is not forthcoming as shown by deterioration of assets quality and depressed profitability, capitalization and assets growth rate which signals rising financial instability risks. Policy makers are grappling with following research questions. Is recent banking sector consolidation threat to stability and long-run sustainability of the Kenyan banks? Is the banking sector "sound and stable' as reported in regulatory reports? What is the role of competition in promoting stability?

This paper offers empirical insights to this debate through examining evaluation of competition and stability conditions in Kenya. This is achieved by evaluating whether adoption of various aspect of consolidation has stifled or promoted competition and stability in Kenya. The paper also goes ahead and examines the role of competition conditions in promoting stability or fragility in Kenya.

\subsection{Objectives of the Study}

Therefore, the objective of this paper is threefold;

i) Firstly, the paper seeks to assess the evolution of competition conditions in the Kenyan banking sector by estimating two competition measures Lerner Index and the Panzar-Rosse H-Statistics;

ii) Secondly, the paper seeks to assess evolution of stability conditions in the Kenyan banking sector by constructing two stability measures Altman Z Score and Bankometer S - Score 
iii) Thirdly, the paper seeks to evaluate the effect of competition on stability in the banking sector in Kenya.

The rest of the paper is structured as follows. Section 2 reviews relevant literature. Section 3 present data and research methodologies issues. Section 4 discusses empirical findings and section 5 present conclusions.

\section{Literature Review}

\subsection{Theoretical Literature}

The importance of banking system stability is widely recognized in the literature. Similarly, promotion of competition through consolidation is also highly recognized. However, the interplay between market power and stability has not received significant attention in the literature, hence remains inconclusive on the role of consolidation in promoting financial stability. Consolidation in literature has normally taken two definitive forms mergers or acquisition and upon close examination reveals three main strands of literature mainly linked to the purpose of consolidation.

The first strand of literature explains banks undertake consolidation for value creation, hence commonly referred to as to value creation theories of mergers and acquisition. This strand of literature explain that managers of banks' make every effort to create value for the bank and also look after the shareholder interest thus they pursue consolidation deals that create synergy from the combined firm hence promoting stability. This is achieved by evaluating takeover premium and integration costs. For example; mergers and acquisition deal do not create value where synergy from mergers and acquisition is lower than the takeover premium and integration costs. However, hubris activities and agency problems sometimes leads to value decreasing consolidation due to tactical motives of the bidder firm leading to fragility of the banking system (Vijgen [9]. The hubris activities imply that acquiring firm managers commit errors of over optimism (winner's curse) in bidding for targets. Roll [10] postulates that managers make an overestimation in evaluating the target firm value and synergy benefits from mergers due to excessive pride or arrogance. Hubris need not to be always taken in a negative sense. Sometimes the intentions may be good, but they make wrong decisions while valuing the target (Weston et al., [11]. Hubris can arise due to over confidence gained in previous successful mergers

The second strand of literature focuses on market power interplay. Market power theory supports the claim that merger gains are the result of increased concentration leading to collusion and monopoly effects. Empirical evidence on whether industry concentration causes reduced competition is not conclusive. However, there is much evidence that concentration is the result of vigorous and continuing competition which causes the changes in market power dynamics as composition of the leading firms adopt to changes over time. In the case of horizontal mergers, decrease in the number of firms increases familiar interdependence, hence creating collusion among the rest of the firm in the industry (Weston et al. [11]. Banks that anticipate 
financial instability problems in the future seek to exit the industry by selling their banks. In their turn, efficient and profitable banks seek expansion opportunities (Hanaan et al. [12]. However, these theories acknowledge problems resulting from agency-shareholder's problems. The agency problem arises when the interest of the appointed managers differs from the interest of the shareholders. It suggests that self-serving managers make ill-conceived consolidation solely to increase firm size and their own compensation rising fragility in long-run (Jensen, [13].

The third strand of literature is based on the differential efficiency theories which postulate that more efficient firms acquires less efficient firms and realize gains by improving their efficiency; this implies excess managerial capabilities in the acquiring firm. Differential efficiency would most likely be a factor in mergers between firms in related industries like the banking sector where the need for improvement could be more easily identified hence promoting system stability. These theories suggest that successful consolidation will only occur when they are expected to generate enough realizable synergies to make the deal beneficial to both parties (Trautwein, [14]. The acquired banks tend to have lower rate of return on assets and higher non-interest expenses compared to non-acquired banks. Difficulty may arise when the acquiring firm overestimates its impact on improving the performance of the acquired firm. This may lead to the acquirer paying too much for the acquired firm hence becoming susceptible to financial instability (Ombaka \& Jagongo [15].

\subsection{Empirical Review}

There are various studies carried out on the area of mergers and acquisition, but most of these studies focus on the performance of the merged institutions, while implication of consolidation on the financial stability has not received adequate focus. Additionally, the existing empirical literature depicts mixed results on the impact of banks consolidation on financial stability. Empirical studies such as Viverita [16], Naba \& Xiaofang [17], Joshua [18], Tuni [19], Agung et.al [2] found positive linkage between consolidation and financial stability. However, Ombaka \& Jagongo [15], Osoro \& Josea [1] didn't not find conclusive empirical evidence of consolidation and stability inter-linkages.

Viverita [16] studied the impact of mergers and acquisitions on bank performance in Indonesia. From a comparison of seven-year pre-merger and post-merger financial performance data, the study revealed that mergers increased a bank's profit potential. The study results indicated improvements in return on assets, return on equity, net interest margin, capital adequacy ratio and non-performing loans after the merger and acquisitions. However, mergers could not improve the financial institutions, ability to perform intermediary functions as indicated by falling loan to deposit ratio.

Naba \& Xiaofang [17] studied the impact of merger and acquisition on the financial performance of West African banks. Three groups of variables were used in the study; liquidity ratio, performance ratios (return on asset and return on equity) and 
investment valuation variables (earnings per share). The study revealed that in terms of liquidity, mergers and acquisitions improves the situation of the banks in the short to long term. It also reveals that performance and investment variables decrease in the period of mergers and acquisitions and increase two or three years later. The study concluded that mergers and acquisition have short and long term positive effects on the liquidity of banks while a negative effect in the short term and a positive effect in the long term on the performance and investment valuation variables.

Joshua [18] evaluated the impact of merger and acquisition on financial efficiency of insurance companies in Nigeria. In his study he used operating profits, net income and net assets of sample companies to determine financial efficiency by comparing data before and after the merger. The study established high post-merger financial efficiency compared to the pre-merger periods.

Tuni [19] studied the impacts of mergers and acquisitions on financial performance of financial institutions in Kenya. The study had two objectives, firstly to determine the financial performance of merged institutions before and after the merger/acquisition and to determine the impact of mergers and acquisitions on the financial performance of the financial institutions. A sample of 20 financial institutions was selected from the population of 70 institutions that had merged. Period of 10 years' financial statements were used to calculate and analyze the performance indicators such as earnings per share, return on asset (ROA), return on equity (ROE). It was found that before the merger, seven institutions had positive ROA, eight institutions had positive ROE and seven institutions had positive EPS. On the year of the merger and acquisitions there was a change in the performance. After the merger and acquisitions, six institutions posted improvement in ROA, eight posted improvement in ROE and eight institutions posted an improvement EPS.

Ombaka \& Jagongo [15] evaluated mergers and acquisition on financial performance among selected banks in Kenya. The study main objective of the study was to establish the influence of mergers and acquisitions on financial performance of commercial banks in Kenya. The study analyzed 9 banks that had merged or acquired in the period 2010 to May 2017. They used performance indicators such as return on asset (ROA), return on equity (ROE) and the liquidity ratio. The study found that the merged institution experienced depressed financial performance. They attributed depressed performance to high levels of uncertainties brought by consolidation which also created high employee turnover. They also found that horizontal mergers led to slower growth due to low resource base while vertical mergers grew faster due to high resource endowment.

\section{Methodology Issues and Data}

\subsection{Data Issues}

This paper used bank-specific, annual financial performance of 37 commercial banks out of a population of 43 commercial banks during the period 2001 to 2017. 
The data was extracted from the sampled banks published financial statements. Six banks from the population were dropped due insufficient data series attributed to consolidation, entrants and exit of commercial banks in the industry. The selected sample period sufficiently covers instances when call for consolidation has been mapped.

\subsection{Measure of Competition}

Literature present two broadly measures of competition conditions namely; structural measures of concentration and non-structural measures. Structural measures of competition are based on the argument that market structure drives firm's conduct which is reflected in performance. Commonly used structural conduct measures of competition are; Herfindahl-Hirschman index (HHI) and the concentration ratios (CR). The major limitation of structural measures of competition is the assumption that higher market power indicated by high ratios, result in super-normal profits due to monopolistic tendencies which is not necessarily true. Also they ignore other factors that may impact competition.

On other hand non- structural measures of competition conditions were developed to overcome structural measures limitation by micro-economic conditions affecting firm's competitive conditions. The common non-structural measures include; Lerner Index advanced by Lerner [20]; Panzar-Rosse H-statistics proposed by Panzer \& Rosse [21] and; Boone Indicator proposed by Boone [22]. Empirical debate is still ongoing effectiveness of Boone Indicator in measuring competition. To achieve first study objective; we constructed two measures of competition namely; Panzar-Rosse H-statistics and Lerner Index to assess the evaluation of competition conditions in the Kenya banking sector.

\subsubsection{Panzar - Rosse H- Statistics}

Panzar-Rosse H-statistics remains the most popular measures of competitions in the empirical literature. The estimated $\mathrm{H}$-statistic falls between 0 and 1 , where closer to 0 is collusive (joint monopoly) competition, closer to 1 indicates monopolistic competition and 1 is perfect competition. To have robust results, a two staged approached is used. First stage is testing for long-run model equilibrium must be undertaken which commonly involves the computation of the Equilibrium (E)statistic in a reduced-form Equation of profitability, using measures such as ROE or ROA as the dependent variable. The resulting E-statistics is supposed to be significantly equal to zero in equilibrium, and significantly negative in case of disequilibrium. This empirical test has traditionally been justified on the grounds that competitive markets will equalize risk-adjusted rates of return across firms such that, in equilibrium, rates of return should not be correlated statistically with factor input prices.

Following Mwega [23], Mlambo \& Ncube [24], Ombongi \& long [25], Kiemo \& Kamau [7] methodology. We estimated E-Statistics using the reduced form profit Equation to test long-run equilibrium conditions in the data, as indicated in Equation 
(1). The E-Statistic is derived as the summation of $\beta_{1+} \beta_{2}+\beta_{3}$ in Equation (1).

$$
\begin{aligned}
& \ln \left(R O A_{i, t}\right)=\alpha+\beta_{1} \ln \left(w 1_{i, t}\right)+\beta_{2} \ln \left(w 2_{i, t}\right)+\beta_{3} \ln \left(w 3_{i, t}\right)+\gamma_{1} \ln \left(n p l_{i, t}\right)+ \\
& \gamma_{2} \ln \left(\text { bsize }_{i, t}\right)+\gamma_{3} \ln \left(i n f_{t}\right)+\gamma_{4} \ln \left(\text { tbill }_{t}\right)+\varepsilon_{i, t}
\end{aligned}
$$

The second stage involves estimating $\mathrm{H}$-statistics similar to the manner prescribed by Panzar-Rosse [21] as shown in Equation (2). H-Statistic is derived as the summation of $\beta_{1+} \beta_{2}+\beta_{3}$, the coefficients of factor input elasticity's prices from Equation (2). Additionally, $\lambda, \beta$ and $\gamma$ represented coefficients of regressors.

$$
\begin{aligned}
& \ln \left(P_{i, t}\right)=\alpha+\beta_{1} \ln \left(w 1_{i, t}\right)+\beta_{2} \ln \left(w 2_{i, t}\right)+\beta_{3} \ln \left(w 3_{i, t}\right)+\gamma_{1} \ln \left(n p l_{i, t}\right)+ \\
& \gamma_{2} \ln \left(\text { bsize }_{i, t}\right)+\gamma_{3} \ln \left(i n f_{t}\right)+\gamma_{4} \ln \left(\text { tbill }_{t}\right)+\varepsilon_{i, t}
\end{aligned}
$$

Where Table 3 present summary variables for estimating E-Statistics and $\mathrm{H}$ Statistics. The signs of the factor input prices in standard practice are difficult to assign a priori, while for two bank-specific variables lognpl and lnbsize are expected to have negative and positive signs respectively. For the macro-economic variables logtbill and loginf are both expected to have negative signs. Table 2 present E-Statistic's and H-Statistics interpretation.

Table 2: E and H Statistic Value Interpretation

\begin{tabular}{|c|c|}
\hline \multicolumn{2}{|c|}{ Equilibrium Test (E-Statistic) } \\
\hline 1st Condition $\mathrm{E}=0$ & Equilibrium \\
\hline 2nd Condition $\mathrm{E}<0$ & Disequilibrium or non-existence of equilibrium \\
\hline \multicolumn{2}{|c|}{ Competitive Conditions (H-Statistics) } \\
\hline 1st Condition $\mathrm{H}<0$ & $\begin{array}{c}\text { Oligopolistic or short run competition, } \\
\text { collusive oligopolistic competition }\end{array}$ \\
\hline 2nd Condition $\mathrm{H}=1$ & Perfect Competition \\
\hline 3rd Condition $0<\mathrm{H}<1$ & Monopolistic Competition. \\
\hline
\end{tabular}

\subsubsection{Lerner Index}

For robustness in measuring competition we also estimated Lerner Index. The Lerner Index measures market power by focusing on the pricing power. This is computed as the difference between price and marginal cost thereby capturing the degree to which a firm can increase its marginal price beyond marginal cost (Lerner [20], Berger et al., [26]. Lerner Index major limitations is that gathering necessary information on prices and costs of firms is almost impossible. Following Gudmundsson, Kisinguh \& Odongo [27], Ndwiga [28] we estimated the Lerner index as a difference between price and marginal cost, divided by price as shown in Equation (3). 


$$
L I_{i t}=\frac{P_{i t}-M C_{i t}}{P_{i t}}
$$

Where LI is the Lerner Index, P is price of bank output (loan), MC is marginal cost, i \& $\mathrm{t}$ represent banks cross sectional and time respectively. $\mathrm{P}$ is calculated as the ratio of total bank gross interest revenue to total assets. MC is estimated on the basis of a translog cost function with one output (total assets) and three input prices (price of labor, price of physical capital, and price of borrowed funds). As specified in Berger et al., [26] symmetry and linear homogeneity restrictions in input prices are imposed and estimate the cost function as follows Equation (4).

$$
\ln T C_{i t}=a_{o}+a_{1} \ln T A_{i t}+\frac{1}{2} a_{2}\left[\ln T A_{i t}\right]^{2}+a_{3} \ln \sum_{j=1}^{3} w_{j i t}+\varepsilon_{i t}
$$

Wj denotes $\mathrm{w} 1, \mathrm{w} 2$, and $\mathrm{w} 3$ indicating three input prices. The estimated coefficients of the cost function are then used for computing the marginal cost. Therefore, marginal cost is equal to the first derivative of the logarithm of total cost function with respect to output multiplied by the ratio of total cost to output. The derivative of the logarithm of the total cost with respect to the logarithm of output is computed using the cost function specified in Equation (4). The marginal cost is based on the estimation of the cost function. We estimate a translog cost function with one output and three input prices as specified in Equation (5). Table 3 present summary variables for estimating Lerner Index.

$M C_{i t}=\frac{T C_{i t}}{T A_{i t}}\left(a_{1}+a_{2} \ln T A_{i t}+a_{3} \ln w_{i t}\right)$

When $\mathrm{P}=\mathrm{MC}$, the Lerner index is zero and the firm has no pricing power. A Lerner index closer to one indicates the higher mark-up of price over marginal costs and hence market power for the firm. $\mathrm{LI}=0$ indicate perfect competition, while $\mathrm{LI}=1$ indicate monopoly.

\subsection{Measures of Bank Stability}

Measuring bank stability has received considerable empirical attention in post 20072009 global financial crisis. Several methodological approaches in measuring banks stability has been adopted by various empirical literatures. These approaches can be broadly categorized as; market based models and accounting based models. Accounting based models employ historical financial statement data such as liquidity, profitability, leverage and assets quality. These models are very popular in assessing financial stability since they are; simple to use, observable and readily available in usable form. Additionally, they rely on observable data, which is free from market distortions driven by information asymmetry (Athanasoglou et.al [29], Altman \& Hotchkiss, [30], Kiemo et.al [31]. Major limitation of, accounting based models is overreliance on accounting information prepared based on conservative 
principles which is prone to critical errors of over or understatement. Additionally, accounting based models rely on irrelevant historical data makes lacking predictive powers of current and future assets values.

On other hand, market based measures of financial stability rely on securities information's held and traded by the firms in the secondary market such as stock returns and valuations which are not observable. The market based models are preferred since they use current and updated securities information hence indicating securities true value (Ohlson [32], Platt \& Platt [33], Kiemo et.al [34]. However, the major drawback of the market based models of predicting financial stability is based on the fact market data is unobservable hence prone to estimation errors and information distortion.

To achieve the paper second objective, we constructed two stability measures namely Altman Z-Score and Bankometer S-Score to evaluate evolution of stability conditions in Kenya.

\subsubsection{Altman Z-Score Measure of Stability}

The post 2007-2009 global financial crisis period witnessed numerous empirical works (such as Jordan et.al [35], Chieng [36], Manousaridis [37]) attempting to evaluate the effectiveness of discriminant analysis, bankruptcy prediction models such as Altman's Z-Score. Majority of these studies focused on bank failures witnessed during the period 2007-2010. Chieng [36] found altman Z" Score model has predictive power of up to five years' pre-bankruptcy. Jordan et.al (2010) found $1 \%$ level the model was able to predict bank failures with $88.2 \%$ accuracy one year prior to failure, $78.6 \%$ two years prior to failure, $71.4 \%$ three years prior to failure, and $66.0 \%$ four years prior to failure. On other hand, Manousaridis [37] findings questioned the Altman Z-score bankruptcy prediction power for private firms operating with high leverage, however the accuracy and predictability for firms from emerging markets was ascertained.

These empirical studies confirmed reliability of Altman z-scores in estimating individual bank fragility as measured by the probability of bankruptcy. Analyst, academician, investors or lenders continue to rely on bankruptcy prediction models to identify and avoid weak banks early enough to prevent loss of value or liquidity associated with such bank failure. However, the biggest limitation of Altman ZScore lies on the fact that the banks/financial institutions usually operate under conditions of high current liabilities, hence current liabilities sometimes exceed current assets on the first variable (Working Capital/Total Assets). Solution to this limitation is adoption of liquidity ratio the first variable to help screening of serious financial problems that a firm could face in the future.

Following the empirical works of Muigai, Muhanji \& Nasieku [38], Kiemo et.al [4], Kiemo et.al [31], Mwangi, Muathe \& Kosimbei [39], Chieng [36] in measuring banks stability conditions, we constructed a stability index (Z-score) as proposed by Altman's Z-Score Model for emerging markets (including banks) as prescribed by Altman [40], Chotalia [41], Altman et.al [42]. The Z- score index measure of bank 
stability is preferred since financial instability can be triggered by multiple factors. Z-scores predict banks with an early stage of capital distress or the probability of failure. We estimated the Z-score score without the specific constant as follows in Equation (6).

$$
\mathrm{Z}_{\mathrm{it}}=3.25+6.56 \mathrm{~A}_{\mathrm{i}, \mathrm{t}}+3.26 \mathrm{~B}_{\mathrm{i}, \mathrm{t}}+6.72 \mathrm{C}_{\mathrm{i}, \mathrm{t}}+1.05 \mathrm{D}_{\mathrm{i}, \mathrm{t}}
$$

Where $\mathrm{A}=$ Working capital / Total Assets, a proxy for measuring liquidity in relation to the size of the bank; B = Retained Earnings / Total Assets, a proxy for measuring bank's capitalization ability through profitability, also it reflects bank's age and earning power; $\mathrm{C}=$ Earnings before Interest and Taxes / Total Assets, a proxy for measuring operational efficiency for long-term viability; and $\mathrm{D}=$ Book Value of Equity / Total Liabilities, a proxy capitalization level for the bank in relation to the total exposure for the bank (for listed companies security prices is applied as numerator to track security market prices fluctuation). While $\mathrm{i}$ and $\mathrm{t}$, indicating the number of cross-sections parameters ranging from 1 to 37 and, time dimensions in terms of years respectively. Table 3 present summary variables for estimating Altman Z-score

The Zones of Discrimination while interpreting the Z-score is as follows; $Z>2.6$, "Safe" Zone- If a bank Z-score falls in this category, the bank is financially stable and there is least probability the bank will face financial instability in near future; $1.1<\mathrm{Z}<2.6$, "Gray" Zone- If a bank falls in the gray area means there is moderate probability that the bank will face financial instability in the near future; $Z<1.1$, "Distress" zone- If a bank z-score falls in this category, there is a very high probability that the bank will face financial instability in near future. A higher zscore corresponds to a higher upper bound of financial stability, implying a higher z-score indicates lower probability of financial instability (Jahn \& Kick, [43].

\subsubsection{Bankometer S-Score Measure of Stability}

For robustness in measuring stability conditions we also estimated Bankometer SScore. A tool advanced by the financial sector policy makers such as International Monetary Fund (IMF), World Bank and central banks to supplement other tools such as "CAMELS" rating system. CAMELS evaluates bank Capital, Asset quality, Management, Earnings, Liquidity, and Sensitivity to market risk to create a watch list of troubled or risky banks to be monitored between on-site examinations. However, CAMELS ratings are kept strictly confidential by the prudential supervisors and are not available to the public (Agung et.al [2] Lepetit \& Strobel [44], Shijaku [45].

Bankometer S-Score was developed following IMF [46] recommendation concerning the assessment of financial health of banks through a publication on 'Macro prudential Indicators of Financial System Soundness. Bankometer S-score were developed using a selected group of CAMELS rating indicators for banks. Empirical works such as Makkar \& Singh [47], Shar, et. al. [48], Onyema et.al [49], 
Kattel [50] have found Bankometer S-score accurate tool in estimating financial health conditions of banks. S-score measure uses; capital asset ratio to measure whether the bank has sufficient capital to support its assets; equity to asset ratio to evaluate the financial health and long term profitability of the banks; capital adequacy ratio to measure of the amount of bank's capital exposure to its risk weighted assets; non-performing loan ratio measuring asset quality of the banks (efficiency); loan to asset ratio as indicator of liquidity conditions in the bank; cost to income ratio to measure bank's costs in relation to its income.

To estimate S-score using Bankometer the following model Equation is employed (7). Table 3 present summary variables for estimating Bankometer S-score.

$$
S_{i t}=1.5 C A_{i t}+1.2 E A_{i t}+3.5 C A R_{i t}+0.6 N P L_{i t}+0.3 C I_{i t}+0.4 L A_{i t}
$$


Table 3: Summary Variables - Notion, Definition and Measurement

\begin{tabular}{|c|c|c|}
\hline Notation & Variable Definition & Measurement \\
\hline \multicolumn{3}{|c|}{ Variables for Estimating of $\mathrm{H}-$ Statistic } \\
\hline$p$ & Output price of loans & Ratio of gross interest revenue over total assets \\
\hline roa & Rate of return & Ratio of net income to total asset \\
\hline$w 1$ & Input price of funds & $\begin{array}{l}\text { Ratio of interest expense over borrowed fund } \\
\text { (deposit }+ \text { Loans) }\end{array}$ \\
\hline$w 2$ & Input price of labour & Ratio of Personnel expenses to total assets \\
\hline w3 & Input price of capital & $\begin{array}{l}\text { Ratio of non-interest operating income to total } \\
\text { assets }\end{array}$ \\
\hline$n p l$ & Banks credit risk & Ratio of non-performing loans over total loans \\
\hline bsize, & Bank size & Total assets \\
\hline inf & Overall prices & Inflation rate \\
\hline tbill & Fiscal policies & 91-day Treasury bill rate \\
\hline \multicolumn{3}{|c|}{ Variables for Estimating of Lerner Index } \\
\hline$T C$ & Total Cost & $\begin{array}{l}\text { Sum of all expenses (personnel, non-interest \& } \\
\text { interest) }\end{array}$ \\
\hline$T A$ & Total Assets & Sum of all assets (current and fixed) \\
\hline$P$ & Price of output (loan) & $\begin{array}{l}\text { Ratio of total bank gross interest revenue to total } \\
\text { assets }\end{array}$ \\
\hline$M C$ & Marginal Cost & First derivative of Total cost function \\
\hline$w 1$ & $\begin{array}{l}\text { Price of borrowed } \\
\text { funds }\end{array}$ & $\begin{array}{l}\text { Ratio of interest expense over borrowed fund } \\
\text { (deposit +loans) }\end{array}$ \\
\hline$w 2$ & Price of labour & Ratio of personnel expenses to total assets \\
\hline$w 3$ & $\begin{array}{l}\text { Price of Physical } \\
\text { capital }\end{array}$ & $\begin{array}{l}\text { Ratio of other non-interest expenses to fixed } \\
\text { assets }\end{array}$ \\
\hline \multicolumn{3}{|c|}{ Variables for Estimating Bankometer S-Score } \\
\hline $\mathrm{CA}$ & Capital Asset Ratio & Ratio of total assets to capital \\
\hline EA & Equity to Asset Ratio & Ratio of total equity to total asset \\
\hline CAR & $\begin{array}{c}\text { Capital Adequacy } \\
\text { Ratio }\end{array}$ & Ratio of total capital to risk weighted assets \\
\hline NPL & $\begin{array}{l}\text { Non-performing Loan } \\
\text { Ratio }\end{array}$ & Ratio of non-performing loan to total loan \\
\hline LA & Loan to Asset Ratio & $\begin{array}{c}\text { Total loans to total assets- indicator of the bank's } \\
\text { liquidity }\end{array}$ \\
\hline $\mathrm{CI}$ & Cost to Income Ratio & $\begin{array}{l}\text { Ratio of operating costs (administrative and fixed } \\
\text { costs, excluding bad debts that have been written } \\
\text { off) to operating income }\end{array}$ \\
\hline$S$ & Solvency Score & $\begin{array}{l}\text { Measure availability of the cash over the long } \\
\text { terms to meet the financial commitment. }\end{array}$ \\
\hline
\end{tabular}


S -Score Interpretation: $S>70$-Termed as solvent \& super sound banks; $50<S>70$ termed gray area, banks susceptible to solvency problems; and $S<50$ - Termed banks not solvent. $i$ and $t$ represent cross-sectional and time dimensions. IMF Recommendations for $S$-Score Variables; CA ration should be more than 4\%; EA ratio must be more than 2\%; CAR ratio minimum 8\% Basel III (CBK 12\%); NPL ratio up to 5\% is acceptable; LA ratio should be below 65\%; CI ratio should be below $40 \%$.

\subsection{Role of Competition in Bank Stability}

To achieve the study third objective, the paper introduces the competition scores generated in Equation (2) and Equation (3) as explanatory variables and stepwise re- estimate bank stability conditions to assess the role of competition in promoting bank stability in Kenya as follows in Equation (8).

$\mathrm{BS}_{\mathrm{it}}=\alpha_{\mathrm{t}}+\ell_{\mathrm{it}-1}+\sum_{\mathrm{i}=1}^{\mathrm{n}} \beta_{\mathrm{i}} \mathrm{x}_{\mathrm{it}}+\gamma_{i}$ competition score ${ }_{\mathrm{it}}+\epsilon_{\mathrm{it}}$

Where, BS - Score measure of stability, $\ell$-is the coefficient of the lagged dependent variable, $\beta$ - is the coefficient matrix of explanatory variables, $X-$ vector of explanatory variables that influences bank stability, competition scorevector of competition scores, $\varepsilon$ - error term, Subscript i - denote the cross-sections and, Subscript $\mathrm{t}$-denote the time-series dimension.

\section{Results and Empirical Findings}

To achieve the study three objectives, we followed methodological approach described in section 3 and the empirical findings are presented and discussed in this section.

\subsection{Evaluating Evolution of Competition Conditions in Kenya}

\subsubsection{Competition Conditions- Panzar-Rosse H-Statistics}

Prior to undertaking regression analysis, we applied panel unit root test, Levin, Lin \& Chu (LLC) (2002) to evaluate whether the data met OLS classical assumption on stationarity. The LLC panel unit test revealed the four variables namely lnbsize, lnw3, lnnpl and lnroa were non-stationarly on level, however they were found to be stationarly on first difference. The other variables namely $\ln p, \ln w 1, \ln w 2$, lntbill and $\operatorname{lninf}$ were stationary on level, similar findings were reported by Kiemo \& Kamau [7].

The study adopted a dynamic panel data Generalized Method of Moments (GMM) regression approach to observe the cross-sectional behavior of the study variables. Panel estimator was selected due to its ability to provide solutions to cross-sectional specific problems. GMM estimator was adopted due to its ability to eliminate measurement errors, endogeneity problems and omitted variables issues through moment restrictions. We followed Hausman [52] recommendation to determine the most appropriate model for our data sample, among the three panel data estimation techniques namely; pooled regression model, fixed effect model and the random 
effect models. Hausman recommendation involves estimating Hausman test for fixed / random effects. The test seeks to establish most appropriate model between the fixed effect model (FEM) and random effect model (REM). This is a test statistic for endogeneity by directly comparing fixed and random effects estimates of coefficients values. The Hausman test revealed REM was the most appropriate.

\section{Testing for Long-Run Equilibrium (E-Statistics)}

To address the first study objective, i.e. evaluating the competition conditions in the Kenya banking sector using $\mathrm{H}$-statistics, we followed a two staged approach. First we estimated Equation (1) aimed at testing the equilibrium conditions by calculating the E-statistics. The regression results are presented in Table 4 column A. The results indicate the E-Statistics calculated from the summation of $\beta 1+\beta 2+\beta 3$, the coefficients of input price elasticities was -0.2933 . We estimated Wald-Statistics (F-Test) to confirm the state of equilibrium for null hypothesis $\mathrm{E}=0$, against the alternative hypothesis $\mathrm{E} \neq 0$. The Wald-Statistics revealed that at 5 percent significance level we cannot reject the null hypothesis, meaning equilibrium holds during the study period. 
Table 4: Panel Regression Results - Competition Conditions in Kenya Banking Sector

\begin{tabular}{|c|c|c|c|}
\hline \multirow[b]{4}{*}{ Dependent Variable } & \multicolumn{3}{|c|}{ First Objective } \\
\hline & \multicolumn{2}{|c|}{ H-Statistics } & \multirow{2}{*}{$\begin{array}{c}\text { Lerner Index } \\
\text { C }\end{array}$} \\
\hline & A & $\mathrm{B}$ & \\
\hline & $\operatorname{lnROA}$ & $\ln \mathrm{P}$ & $\operatorname{lnTC}$ \\
\hline Intercept & $\begin{array}{c}-3.622 * * * \\
(-10.26)\end{array}$ & $\begin{array}{c}-0.322 * * \\
(-2.48)\end{array}$ & $\begin{array}{l}-0.446 \\
(-1.21)\end{array}$ \\
\hline Lnw1 & $\begin{array}{c}-0.084 * * \\
(-2.22)\end{array}$ & $\begin{array}{c}0.345^{* * *} \\
(23.70)\end{array}$ & $\begin{array}{c}0.309 * * * \\
(23.96)\end{array}$ \\
\hline Lnw2 & $\begin{array}{c}-0.403^{* * *} \\
(-5.23)\end{array}$ & $\begin{array}{c}0.262 * * * \\
(9.40)\end{array}$ & $\begin{array}{c}0.506^{* * * *} \\
(18.03)\end{array}$ \\
\hline Lnw3 & $\begin{array}{c}0.196^{* * *} \\
(3.11)\end{array}$ & $\begin{array}{l}-0.020 \\
(-0.91)\end{array}$ & $\begin{array}{c}0.031^{*} \\
(0.08)\end{array}$ \\
\hline lnnpl & $\begin{array}{l}-0.060 \\
(-0.99) \\
\end{array}$ & $\begin{array}{l}0.002 \\
(0.10)\end{array}$ & \\
\hline lnbsize & $\begin{array}{c}0.509 * * * \\
(2.85)\end{array}$ & $\begin{array}{l}0.116^{*} \\
(1.72)\end{array}$ & \\
\hline lntbll & $\begin{array}{l}-0.031 \\
(-0.69) \\
\end{array}$ & $\begin{array}{l}0.015 \\
(0.82)\end{array}$ & \\
\hline $\operatorname{lninf}$ & $\begin{array}{l}0.083^{*} \\
(1.713)\end{array}$ & $\begin{array}{l}-0.008 \\
(-0.40)\end{array}$ & \\
\hline lnta & & & $\begin{array}{c}1.235^{* * * *} \\
(16.01)\end{array}$ \\
\hline $0.5(\operatorname{lnta})^{2}$ & & & $\begin{array}{c}-0.025^{* *} \\
(-3.19)\end{array}$ \\
\hline Adjusted R-squared & 0.104 & 0.557 & 0.963 \\
\hline Durbin-Watson stat & 2.272 & 0.792 & 0.890 \\
\hline S.E. of regression & 0.4857 & 0.221 & 0.191 \\
\hline $\operatorname{Prob}(J$-statistic) & 0.000 & & 0.000 \\
\hline Equilibrium Test & & & \\
\hline E-Statistic & -0.293 & & \\
\hline Wald Test (F-stat) for $E=0$ & 7.417 & & \\
\hline Probability Value & 0.067 & & \\
\hline H-Statistics & & 0.587 & \\
\hline Wald Test (F-stat) for $\mathrm{H}=1$ & & 20.786 & \\
\hline Probability Value & & 0.000 & \\
\hline Wald Test (F-stat) for $\mathrm{H}=0$ & & 3.280 & \\
\hline Probability Value & & 0.071 & \\
\hline Number of observations & 580 & 580 & 580 \\
\hline
\end{tabular}

NB: $t$-values in parentheses; $* * * 1 \%$ level of significance; $* * 5 \%$ level of significance; $* 10 \%$ level of significance. 


\section{Estimating H-Statistic}

Once long-run equilibrium condition was met we proceeded to estimate Equation (2) to calculate the $\mathrm{H}$-statistics and results presented in Table 4, Column B. The Table revealed $\mathrm{H}$-statistics computed from the summation of $\beta 1+\beta 2+\beta 3$, the coefficients of input price elasticities was 0.586674 . This means competitive conditions is increasing in Kenya during the study period and can be characterized as monopolistic competition (3rd condition $0<\mathrm{H}<1$ ). The Table also revealed, as expected in apriori, the bank- specific control variable $b$ size had positive coefficient and significant at 10 percent indicating as the bank total assets increased, the output price of loans $p$ also increased. Similarly, as expected, the macro-economic variables lntbill and lninf had a positive and negative coefficient respectively; however, they were not significant at 10 percent. The positive coefficient for the variable lntbill, confirm the fiscal policy influence of banks performance through government securities in Kenya. On other hand the negative coefficient of the lninf, indicate the distortions on the output prices of bank loans brought by rising inflation. The Table 4, column B also reveals that the coefficients of input price of funds (lnw1) and input price of labor (lnw2) were positive and significant at 1 percent. This can be interpreted to mean as the prices of funds and labor increases, the banks output price of loans rises too in Kenya. On other hand, the coefficient of the input price of capital (Inw3) was negative but not statistically significant. Our study findings are in concurrence with previous studies on Kenya such as Mwega [23], Ombongi \& Long [25], Talam \& Kiemo [54].

\subsubsection{Evaluating Market Power - Lerner Index}

For robustness in addressing first objective of evaluating competition conditions in Kenya, we estimated Equation (3), this was after estimating the Equation (4) to get the coefficients for estimating MC as described in Equation (5). The estimation results for Equation (4) are presented in Table 4, column C.

The results of Lerner Index estimated using Equation (3) is presented in Table 5. Table 5 reveals Lerner Index findings support the $\mathrm{H}$-statistics findings that, competition condition in Kenya was increasing during the study period as shown by downward trend of Lerner Index for the industry. The overall industry Lerner Index was reported at 0.30 in 2001 and closed at 0.28 in 2017 . The industry average Lerner Index during the study period was 0.31 . The 0.28 standard deviation indicate slight variations across individual banks Lerner Index. This study finding support the empirical findings of Ndwiga [28] who found the Lerner Index was declining during the 2003-2017 study period, indicating the sector was becoming less concentrated. However, this study findings contrast Gudmundsson et.al [27] findings that competition in the Kenyan banking sector was declining over 20002001 study period. 


\subsection{Evaluating Evolution of Banks Stability Conditions}

\subsubsection{Estimating Altman Z-Score Statistics}

To address the second study objective, i.e. evaluating the stability conditions in the Kenya banking sector using Z-Score statistics, we estimated Equation (6) as prescribed. Table 6 present the Z-score statistics for commercial banks in Kenya using the CBK [53] commercial banks peer group classification. The Table reveals the overall banking sector in Kenya remained within the "Safe" Zone, during the period under study as indicated by Z-Score falling within the rage of $Z>2.6$. This can be inferred to mean, banks in Kenya are financially healthy and faced least probability of experiencing financial instability in the near future. However, the standard deviation of 0.82 indicates there is widespread variation across the individual banks, with highest Z-score at 10.1, lowest Z-score at 1.9, while industry means Z-score was at 4.9. The overall industry Z-score remained stable and healthy across the study period closing at Z-score of 4.86 in 2017 compared to Z-score of 4.92 reported in 2001, translating only 1.3 percent decline over the 17 years' study period. The industry decline is attributed to decline of stability conditions among the small peer group banks.

Table 5: Evolution of Competition Conditions - Lerner Index

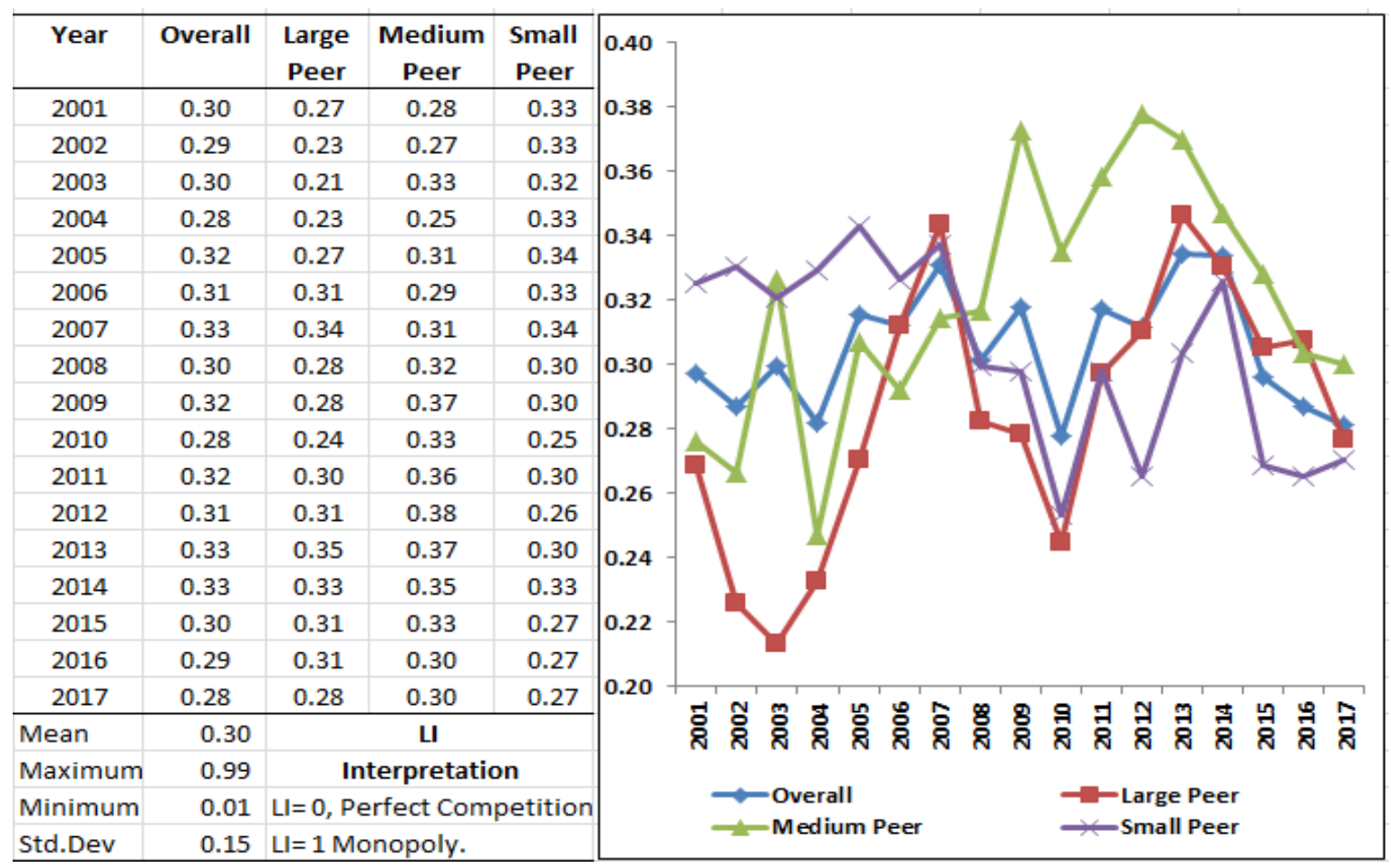

Table 6 also reveals that, stability conditions among the large peer group improved by 9.4 percent across the study period to close at z-score of 5.1 in 2017 compared to $\mathrm{z}$-score of 4.7 reported in 2001 . Medium peer banks recorded only 1 percent 
improvement in the stability conditions during the study period. On other hand, the small peer group banks experienced highest level of decline in stability conditions. At the start of the study period, small peer group experienced highest level of stability as indicated by at Z-score 5.5; however, from period 2006, these peer group banks started experiencing decline in stability conditions to the lowest level recorded at z-score of 5.0 in 2017 (Figure 4). The significant drop at the tail end of the study period can be attributed to the fact, small peer groups were largely negatively affected by the banking sector instability experienced in Kenya during year 2015, 2016 with placement of three banks into receivership by CBK. During this period the small peer group banks experienced deposits 'flight to safety' as customer's deposit moved from small banks to large banks.

Table 6: Evolution of Stability Conditions in Kenya - Z \& S- Scores Measures

\begin{tabular}{|c|c|c|c|c|c|c|c|c|}
\hline & \multicolumn{2}{|c|}{ Overall } & \multicolumn{2}{|c|}{ Large Peer } & \multicolumn{2}{|c|}{ Medium Peer } & \multirow{2}{*}{\multicolumn{2}{|c|}{ Small Peer }} \\
\hline Year & S_Score & Z_Score & S_Score & Z_Score & S_Score & Z_Score & & \\
\hline 2001 & 210 & 4.9 & 170 & 4.7 & 208 & 4.8 & 245 & 5.5 \\
\hline 2002 & 217 & 5.0 & 156 & 4.4 & 204 & 4.9 & 270 & 5.7 \\
\hline 2003 & 210 & 5.0 & 148 & 4.4 & 181 & 4.7 & 275 & 5.9 \\
\hline 2004 & 201 & 4.9 & 152 & 4.5 & 168 & 4.6 & 262 & 5.8 \\
\hline 2005 & 195 & 4.9 & 141 & 4.5 & 156 & 4.5 & 262 & 5.7 \\
\hline 2006 & 185 & 4.8 & 139 & 4.6 & 159 & 4.7 & 239 & 5.4 \\
\hline 2007 & 182 & 4.9 & 160 & 4.8 & 149 & 4.7 & 228 & 5.4 \\
\hline 2008 & 181 & 4.9 & 143 & 4.7 & 161 & 4.8 & 226 & 5.3 \\
\hline 2009 & 179 & 4.9 & 150 & 4.9 & 160 & 4.8 & 219 & 5.3 \\
\hline 2010 & 177 & 5.0 & 148 & 5.1 & 163 & 4.9 & 214 & 5.3 \\
\hline 2011 & 170 & 4.9 & 142 & 5.1 & 155 & 4.8 & 205 & 5.2 \\
\hline 2012 & 180 & 4.9 & 159 & 5.2 & 169 & 4.7 & 209 & 5.2 \\
\hline 2013 & 175 & 4.9 & 164 & 5.3 & 167 & 4.8 & 198 & 5.1 \\
\hline 2014 & 166 & 5.0 & 156 & 5.4 & 161 & 4.9 & 186 & 5.1 \\
\hline 2015 & 168 & 5.0 & 154 & 5.2 & 158 & 4.9 & 193 & 5.2 \\
\hline 2016 & 175 & 5.0 & 152 & 5.1 & 170 & 4.9 & 202 & 5.2 \\
\hline 2017 & 173 & 4.9 & 152 & 5.1 & 168 & 4.8 & 197 & 5.0 \\
\hline Mean & 185 & 4.9 & Z_Sc & re Interpr & tation & S_Sc & Interpr & tation \\
\hline Maximum & 526 & 10.1 & $\mathrm{Z}>2$. & 'Stability & Zone & $S>7$ & Stability & Zone \\
\hline Minimum & 96 & 1.9 & $1.1<\mathrm{Z}$ & 2.6 'Gra & 'Zone & $50<S$ & 70 'Gray' & Zone \\
\hline Std. Dev & 63.1 & 0.8 & $\mathrm{Z}<1$ & 'Distress & Zone & $\mathrm{S}<5$ & 'Distress' & Zone \\
\hline
\end{tabular}

\subsubsection{Estimating Bankometer S-Score}

For robustness in addressing second objective of evaluating stability conditions in Kenya, we estimated Equation (7) and the results are presented in Table 6. The S- 
score findings support the Z-Score findings that overall banking sector in Kenya remained within the "Safe" Zone, during the period under study as indicated by SScore falling within the rage of $S>70$. This can be inferred to mean, banks in Kenya are financially healthy and faced least probability of experiencing financial solvency problems in the near future. However, the large standard deviation of 63 indicates there is widespread variation across the individual banks, with highest Sscore at 526, lowest S-score at 96, while industry means S-score was at 185 . The overall industry S-score remained high and stable across the study period closing at S-score of 173 in 2017 compared to S-score of 210 reported in 2001, translating 17 percent decline over the 17 years' study period. Unlike the Z-Score findings, where the industry decline was attributed to decline of stability conditions among the small peer group banks, for S-Score decline in stability conditions is evidenced across the three peer group classifications. Large peer group recorded 11 percent decline, Medium peer group recorded 19 percent decline while small peer group recorded 20 percent decline.

Both Z-Score and S-Score statistics findings reveals that, despite Kenyan banks experiencing high stability conditions across the study period, the stability conditions is on downward trend across the three peer groups during the study period (Figure 4).

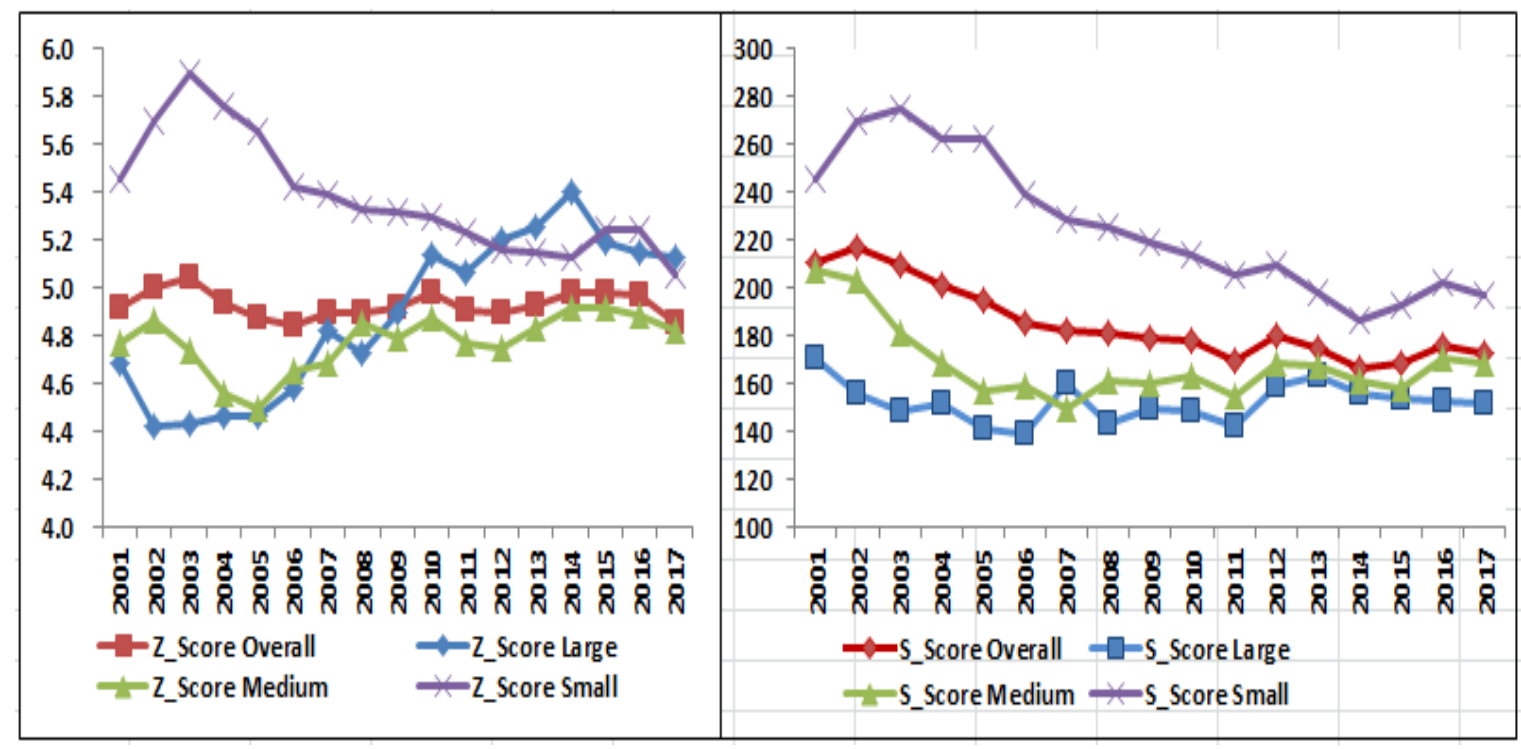

Figure 4: Evolution of Z \& S Score- Measure of Stability Conditions in Kenya 


\subsection{Evaluating Role of Competition in Bank Stability}

Finally, to achieve the study third objective, we estimated Equation (8) as prescribed. The paper adopted dynamic panel data GMM estimators as described in section 4.1. Table 7 present the regression results.

From the Table 7, column A \& column $\mathrm{C}$ its evidence that the coefficients of $\mathrm{H}$ statistic was positive and significant at 5 percent level of significance for equations with $\mathrm{Z}$-score and $\mathrm{S}$-score as dependent variable. This implies positive changes in level of competition leads to corresponding positive changes in stability conditions and vice versa, for banking sector in Kenya for the period under study. On other hand, Table 7, Column B and D, indicate the coefficients of Lerner Index were positive, but insignificant for equations with Z-score and S-score as dependent variable. 
Table 7: Panel Regression Results - Role of Competition in Promoting Stability

\begin{tabular}{|c|c|c|c|c|}
\hline \multirow{3}{*}{$\begin{array}{c}\text { Dependent } \\
\text { Variable }\end{array}$} & \multicolumn{4}{|c|}{ Third Objective } \\
\hline & $\mathbf{A}$ & B & C & D \\
\hline & \multicolumn{2}{|c|}{ Z-Score } & \multicolumn{2}{|c|}{ S-Score } \\
\hline Intercept & $\begin{array}{c}0.761 * * * \\
(4.05)\end{array}$ & $\begin{array}{c}0.590 * * * \\
(3.44)\end{array}$ & $\begin{array}{l}0.246^{*} \\
(1.93)\end{array}$ & $\begin{array}{c}0.365^{* *} \\
(3.21)\end{array}$ \\
\hline $\mathrm{Z}(-1)$ & $\begin{array}{c}0.860 * * * \\
(46.01)\end{array}$ & $\begin{array}{c}0.864 * * * \\
(46.11)\end{array}$ & & \\
\hline$S(-1)$ & & & $\begin{array}{c}0.815^{* * *} * \\
(39.24)\end{array}$ & $\begin{array}{c}0.803 * * * \\
(38.56)\end{array}$ \\
\hline $\mathrm{npl}$ & & & & $\begin{array}{c}0.804 * * * \\
(5.25)\end{array}$ \\
\hline $\mathrm{Npl}(-1)$ & $\begin{array}{l}0.125 \\
(1.31)\end{array}$ & $\begin{array}{l}0.052 \\
(0.58)\end{array}$ & $\begin{array}{l}0.133^{*} \\
(1.88)\end{array}$ & $\begin{array}{c}-0.472 * * \\
(-3.25)\end{array}$ \\
\hline $\operatorname{Inf}(-1)$ & $\begin{array}{l}-0.305 \\
(0.33)\end{array}$ & $\begin{array}{l}-0.401 \\
(-1.24)\end{array}$ & $\begin{array}{l}0.171 \\
(0.77)\end{array}$ & $\begin{array}{l}0.181 \\
(0.80)\end{array}$ \\
\hline gdpr & & $\begin{array}{l}-1.110 \\
(-1.47)\end{array}$ & & $\begin{array}{l}0.079 \\
(0.15)\end{array}$ \\
\hline gdpr(-1) & $\begin{array}{l}0.896 \\
(1.23)\end{array}$ & $\begin{array}{l}0.781 \\
(1.07)\end{array}$ & $\begin{array}{l}0.710 \\
(1.38)\end{array}$ & $\begin{array}{c}0.886^{*} \\
(1.73)\end{array}$ \\
\hline lnbsize & $\begin{array}{l}0.004 \\
(0.32)\end{array}$ & $\begin{array}{l}0.010 \\
(0.89)\end{array}$ & $\begin{array}{l}-0.013 \\
(-1.38)\end{array}$ & $\begin{array}{l}-0.017 * \\
(-1.86)\end{array}$ \\
\hline H-Statistics & $\begin{array}{c}0.503^{* *} \\
(2.37)\end{array}$ & & $\begin{array}{c}0.392 * * \\
(2.62)\end{array}$ & \\
\hline Lerner Index & & $\begin{array}{l}0.031 \\
(0.31)\end{array}$ & & $\begin{array}{c}0.0946 \\
(1.3165)\end{array}$ \\
\hline Adjusted R-squared & 0.789 & 0.785 & 0.812 & 0.818 \\
\hline Durbin-Watson & 2.160 & 2.142 & 1.916 & 1.923 \\
\hline S.E. of regression & 0.368 & 0.369 & 0.264 & 0.260 \\
\hline $\operatorname{Prob}(J$-statistic) & 0.000 & 0.000 & 0.000 & 0.000 \\
\hline Observations & 591 & 591 & 591 & 591 \\
\hline
\end{tabular}

NB: t-values in parentheses; $* * * 1 \%$ level of significance; $* * 5 \%$ level of significance; * $10 \%$ level of significance. 


\section{Conclusion and Policy Recommendations}

The paper sought to examine evaluation of competition and stability conditions in the Kenya banking sector amidst adoption of various aspect of consolidation. This was achieved by exploring evaluation of competition and stability using bank-level and peer-level annual data from 2001 to 2017. The paper estimated two competition measures namely Lerner Index and Panzar-Rosse H statistics to assess competition conditions. Both measures indicated competition conditions for banking sector in Kenya is increasing and can be characterized as monopolistic competition. The overall industry H-Statistics and Lerner Index Score during the study period was found to be 0.59 and 0.31 respectively.

The paper also estimated two stability measures namely Altman Z-Score and Bankometer S-Score to assess stability conditions. The findings of the both measures indicate the banking sector stability conditions in Kenya during the period of the study was high and sound, though on downward sloping. Overall industry Altman Z-Score and Bankometer S-Score during the study period was found to be 4.9 and 185 respectively.

On the role of competition in promoting stability in the Kenya banking sector, the study found positive and significant impact of competition conditions measured $\mathrm{H}$ statistics and Lerner Index on stability conditions measured by both Z \& S-scores. This implies competition promote stability conditions in Kenya banking sector for the period of the study.

The paper concludes that, adoption of various aspect of banking sector consolidation has led to improved competition and stability conditions in Kenya. Banking sectors players should continue implementing and adopting various policies that promote competition and stability such as market driven consolidation.

\section{ACKNOWLEDGEMENTS.}

The views expressed in this study are solely those of the authors and do not necessarily reflect the views of the Central Bank of Kenya. 


\section{References}

[1] Osoro, J., \& Josea, K. (2019). Market Power and Intermediation Efficiency in Kenya: Blind Spots and Empirical Clarity. Kenya Bankers Working Paper Series, 2019.

[2] Agung, R., Atiti, F., \& Kimani, S. (2019). Competition and Banking Sector Stability in Kenya. Kenya Bankers Working Paper Series, 2019.

[3] Osoro, J., \& Muriithi, D. (2017). The Interbank Market in Kenya. Kenya Bankers Working Paper Series, 2017.

Online access; https://www.kba.co.ke/downloads/WPS\%2017.pdf

[4] Kiemo, S., \& Talam, C. C. (2019). De-risking Opportunities for Banks: Examining Productivity of Sectoral Bank Credit Flows. Kenya Bankers Working Paper Series, 2019.

Online access; https://www.kba.co.ke/downloads/WPS-05-2019.pdf

[5] International Finance Corporation [IFC]. (2016). De-Risking by Banks in Emerging Markets -Effects and Responses for Trade. EM Compass Note 24, November.

[6] International Monetary Fund [IMF]. (2016). The Withdrawal of Correspondent Banking Relationships: A Case for Policy Action. IMF Staff Discussion Note SDN/16/07, June.

[7] Kiemo, S., \& Kamau, A. (2019). Banking Sector Competition and Efficiency in Kenya. Kenya Bankers Working Paper Series, 2019.

[8] Central Bank of Kenya (CBK). (2019): The Kenya Financial Sector Stability Report 2018, September 2019 Issue no. 16.

[9] Vijgen, D., (2007). Shareholders wealth effects on mergers and acquisition in the Western part of Continental Europe, University of Maastricht.

[10] Roll, R. (1986). The Hubris hypothesis of corporate takeovers, Journal of Business 59, 197-216.

[11] Weston, J.F., Mitchel, M.L.,Mulherin,J.H. and Salwan, P. (2010). Takeovers, restructuring, and corporate governance. Fourth ed. Delhi: Pearson Education.

[12] Hanaan, T., and Pilloff, S. (2009). Acquisition Targets and Motives in the Banking Industry, Journal of Money, Credit and Banking, vol.41, no.6, pp.1167-1187.

[13] Jensen, M.C (1986). Agency costs of free cash flows, corporate finance, and takeovers, American Economic Review 76, pp. 323-329.

[14] Trautwein, F (1990). Mergers motives and managerial prescriptions, strategic management journal, Vol.11 (4), pp. 283-295.

[15] Ombaka, C \& Jagongo, A. (2018). Mergers and acquisition on financial performance among selected commercial banks, Kenya. International Academic Journal of Economics and Finance, 3(1), 1-23.

[16] Viverita, (2008). The effects of mergers on bank performance; Evidence from bank consolidation policy in Indonesia. International Review of business Research Papers 4: (4), 368-380. 
[17] Naba, B. M., Xiaofang. C., (2014). The Impact of Mergers and Acquisition on the financial performance of West African Banks: A case study of some selected commercial banks, International Journal of Education and Research.

[18] Joshua, O. (2011). Comparative analysis of the impact of mergers and acquisitions on financial efficiency in Nigeria. Journal of Accounting and Taxation, pg 1-7.

[19] Tuni Majala and Mwalakundi (2011). The impact of mergers and acquisition on financial performance of commercial banks in Kenya, Unpublished MBA Thesis, University of Nairobi.

[20] Lerner, A. P. (1934). The Concept of Monopoly and the Measurement of Monopoly Power. The Review of Economic Studies. 1 (3): 157-175.

[21] Panzar, J. C., \& Rosse, J. N. (1987). Testing for" monopoly" equilibrium. The journal of industrial economics, 443-456.

[22] Boone, J. (2008). A new way to measure competition. The Economic Journal, $118(531), 1245-1261$.

[23] Mwega, F. (2011). The competitiveness and efficiency of the financial services sector in Africa: A case study of kenya. African Development Review, 23(1), 44-59.

[24] Mlambo, K., \& Ncube, M. (2011). Competition and efficiency in the banking sector in South Africa. African Development Review, 23(1), 4-15.

[25] Ombongi, P. N., \& Long, W. (2018). Assessing Nature of Competition in Kenya's Banking Sector. International Journal of Research in Business Studies and Management, 5(2), 11-19.

[26] Berger, A.N., Klapper, L.F., and Turk-Ariss, R. (2009). Bank competition and financial stability. Journal of Financial Services Research, vol. 35, 99-118.

[27] Gudmundsson, R., Ngoka-Kisinguh, K., \& Odongo, M. T. (2013). The role of capital requirements on bank competition and stability: The case of the Kenyan banking industry. Kenya Bankers Association-KBA Centre for Research on Financial Markets and Policy Working Paper Series.

[28] Ndwiga, D. (2019). The Effects of Fintechs on Bank Market Power and Risk Taking Behaviour in Kenya. Kenya Bankers Association Working Paper Series, 2019.

[29] Athanasoglou, P., Delis, M. \& Staikouras, C. (2006). Determinants of Banking Profitability in South Eastern European Region. Bank of Greece Working Paper, 06/07.

[30] Altman, E. I., \& Hotchkiss, E. (1993). Corporate financial distress and bankruptcy.

[31] Kiemo, S. M., Olweny, T. O., Muturi, W. M., \& Mwangi, L. W. (2019). BankSpecific Determinants of Commercial Banks Financial Stability in Kenya. Journal of Applied Finance and Banking, 9(1), 119-145.

[32] Ohlson, J.A., (1980). Financial ratios and the probabilistic prediction of bankruptcy. Journal of accounting research, pp.109-131. 
[33] Platt, H.D. \& Platt, M.B. (2002). Predicting corporate financial distress: reflections on choice-based sample bias. Journal of Economics and Finance, 26(2), pp.184-199.

[34] Kiemo, S. M., Muturi, W. M., Olweny, T. O., \& Mwangi, L. W. (2018). The Moderating Effect of Economic Growth on the Relationship between BankSpecific Determinants of Commercial Banks Financial Stability in Kenya. International Journal of Economics, Commerce and Management. United Kingdom. Vol. VI, Issue 9, September 2018.

[35] Jordan, Dan J. and Rice, Douglas and Sanchez, Jacques and Walker, Christopher and Wort, Donald Henry. (2010). Predicting Bank Failures: Evidence from 2007 to 2010.

Available at SSRN: https://ssrn.com/abstract=1652924 or http://dx.doi.org/10.2139/ssrn.1652924.

[36] Chieng, J. (2013). Verifying the Validity of Altman's Z" Score as a Predictor of Bank Failures in the Case of the Eurozone (Doctoral dissertation, Dublin, National College of Ireland).

[37] Manousaridis, C. O. (2017). Z-Altman's model effectiveness in bank failure prediction-The case of European banks.

[38] Muigai. R. G. Muhanji., S. \& Nasieku., T. (2015). Determinants of Financial Soundness Among Non-Financial Companies Listed in Nairobi Securities Exchange, Kenya. International Journal of Economics and Finance 4 (12), 120.

[39] Mwangi, L. W., Makau, M. S., \& Kosimbei, G. (2014).

Relationship between capital structure and performance of non-financial companies listed in the Nairobi Securities Exchange, Kenya.

Global Journal of Contemporary Research in Accounting, Auditing and Business Ethics, 1(2), 72-90.

[40] Altman, Edward I. (2002). Revisiting Credit Scoring Models in a Basel 2 Environment (May 2002). NYU Working Paper No. S-CDM-02-06. Available at SSRN: https://ssrn.com/abstract=1295815.

[41] Chotalia, Parul. (2014). Evaluation of Financial Health of Sampled Private Sector Banks with Altman Z-score Model International Journal of Research in Management, Science \& Technology (E-ISSN: 2321-3264) Vol. 2, No. 3.

[42] Altman, E. I., Hartzell, J., \& Peck, M. (1998). Emerging market corporate bonds-A scoring system. In Emerging market capital flows (pp. 391-400). Springer, Boston, MA.

[43] Jahn N. \& Kick T. (2012). Determinants of Commercial banks Financial stability: A Macro-Prudential Analysis. Deutsche Bundesbank Discussion Paper.

[44] Lepetit, L., \& Strobel, F. (2014).

Bank income smoothing, ownership concentration and the regulatory environment. Journal of Banking \& Finance, 41, 253-270.

[45] Shijaku, G. ( 2017). Bank Stability and Competition. Evidence from Albania Banking Market. 
[46] International Monetary Fund [IMF]. (2000). Macro prudential Indicators of Financial System Soundness. International Monetary Fund.

[47] Makkar, A., \& Singh, S. (2012). Evaluating the Financial Soundness of Indian. National Conference on Emerging Challenges for Sustainable Business 2012, (pp. 118-132).

[48] Shar, A. H., Shah, M. A., \& Jamali, H. (2010). Performance Evaluation of banking sector In Paskisthan. International Journaal of Business and Management, 5 (8), 113-118.

[49] Onyema J. I., Okey N., Precious O., Amadi S., N. (2018). Evaluation of financial soundness of selected commercial banks in Nigeria: An application of Bankometer S-score model. J Fin Mark.;2(4):22-24.

[50] Kattel, I. (2015). Evaluating the Financial Solvency of Selected Commercial Banks of Nepal: An Application of Bankometer. Journal of Advanced Academic Research, 1(1), 88-95. https://doi.org/10.3126/jaar.v1i1.13518.

[51] Levin, A., Lin, C. F., \& Chu, C. S. J. (2002). Unit root tests in panel data: asymptotic and finite-sample properties. Journal of econometrics, 108(1), 124.

[52] Hausman, J. A. (1978). Specification tests in econometrics. Econometrica: Journal of the econometric society, 1251-1271.

[53] Central Bank of Kenya (CBK). (2018). Bank Supervision Annual Report 2017

[54] Talam, C.C., \& Kiemo. S.M. (2017). Competition and Financial Sector Development in Kenya. Macroeconomic and Financial Management Institute of Eastern and Southern Africa (MEFMI) Research \& Policy Journal Issue 3, 6-44. 